\title{
Types of Shiite jurisprudents' Reference to the Practical Sire of the Holy Prophet (PBUH) and Imams (AS)
}

\author{
Mehran Khadem Marzoudi ${ }^{1}$, Hossein Saberi ${ }^{1} \&$ Mohammad Taghi Fakhlaei ${ }^{1}$ \\ ${ }^{1}$ Faculty of Theology and Islamic Sciences, Ferdowsi University of Mashhad, Mashhad, Iran \\ Correspondence: Hossein Saberi, Faculty of Theology and Islamic Sciences, Ferdowsi University of Mashhad, \\ Mashhad, Iran. E-mail: saberi@ferdowsi.um.ac.ir
}

Received: January 19, 2017

Accepted: February 13, $2017 \quad$ Online Published: February 28, 2017

doi:10.5539/jpl.v10n2p220

URL: https://doi.org/10.5539/jpl.v10n2p220

\begin{abstract}
Based on the viewpoint shared by Shiite jurisprudents, the second source of jurisprudence is "Sire". The Holy Prophet (PBUH) and Imams' (AS) words and deeds that are called "Sire" are considered as religious justification used as a reason for inferring from religious orders.

In order to infer from religious orders, jurisprudents refer to the Holy Prophet (PBUH) and Imams' (AS) practical Sire which aimed at explaining an issue or removing its ambiguity as an independently supportive reason to prove their claim.

The intention of investigating this subject was to gain an understanding of the Shiite jurisprudents' approach to dealing with the Holy Prophet (PBUH) and Imams' (AS) deeds as well as discovering the jurisprudents' position to their deeds, i.e. to find out if they deal with the deeds the same way as they deal with the words or not.

In this study, it was tried to investigate types of Shiite jurisprudents' reference to the practical Sire of the Holy Prophet (PBUH) and Imams (AS) and explain the viewpoints shared by the jurisprudents. Authentic sources of Islamic jurisprudence were benefitted from in this study.

Types of jurisprudents' reference to obligation, recommendation, etc. were mentioned in this study. Also, the difference between words and deeds of the Holy Prophet (PBUH) and Imams (AS) and the domain of their practical reasonability as well were discussed. Types of jurisprudents' reference to the practical Sire of the Holy Prophet (PBUH) and Imams (AS) were discussed, too.
\end{abstract}

Keywords: the practical Sire of the Holy Prophet (PBUH) and Imams (AS), reasonability of the practical Sire, reference to the practical Sire

\section{Introduction}

Supreme Shiite jurisprudents refer to or infer from religious orders in four sources: the Holy Quran, Sire, consensus and wisdom which are known as "the four reasons". Definitely, the present study was not aimed at investigating the entire aspects of these four sources. As it is indicated from the title, the purpose of this study was to investigate types of Shiite jurisprudents' reference to the practical Sire of the Holy Prophet (PBUH) and Imams (AS) that forms a part of the Sire.

This research study tried to investigate and assess the ways supreme jurisprudents deal with the practical Sire of the Holy Prophet (PBUH) and Imams (AS). Prior to the main discussion, some related generalities are required to be briefly illustrated.

\section{Types of Deeds by the Holy Prophet (PBUH) and Imams (AS)}

It is of no doubt that the Holy Prophet (PBUH) and Imams' (AS) deeds are a source of reference and inference of religious orders. The Holy Prophet (PBUH) and Imams' (AS) deeds imply the legitimacy of the practice and, but their abandoned deeds imply the illegitimacy of the practice. However, in some cases, their deeds or abandoned deeds have implications beyond legitimacy or illegitimacy. The examples are as follows:

1) If the Holy Prophet (PBUH) and Imams (AS) do a deed as a means of "teaching", the scope of such a deed will expand. For example, if the Imam (AS) practices a deed like teaching how to say prayers or make ablutions in the presence of an individual or individuals, then the situations and components of that deed (prayers or ablutions) can be applied from the Imam's practice. The jurisprudents' reference to the narrations describing the 
Holy Prophet (PBUH) and Imams' (AS) deeds about ablutions, prayers, Hajj etc. is in this regard.

2) In cases where the Holy Prophet (PBUH) and Imams' (AS) deed is practiced constantly and continuously in a way that the abandoned deeds are few, or in cases where abandoning the deed is in progress in a way that the items of practice are few. It is more or less inferred from this description that in the first case such a deed implies recommendation and in the second case the abandoning of the deed implies abomination.

3) In cases where the Holy Prophet (PBUH) and Imams' (AS) constant adherence to a deed is verified, in a way that they are not willing to abandon the deed, it will be more or less applied or considered as incumbent.

\subsection{Jurisprudents' Viewpoints}

In this regard, Bahrani-Al-Asfoor says: "The general rule is that whenever the deed represents ambiguity in Sire or the Holy Quran, obligation to it is indispensable unless a distinct reason implies its recommendation" (Bahrani, 162).

Mohammad Bagher Behbahani says: "According to the existing views, although the truth is not in incumbency, whenever the Holy Prophet (PBUH) and Imams' (AS) deed is aimed at expressing an ambiguity, the application of it is indispensable, since certain exculpation and obedience to the rules order for its application. If the mode of the deed is not known, obligation to it is recommended" (Behbahani, 2003, p. 70).

However, Mirzaye Qomi says: "The Holy Prophet (PBUH) and Imams' (AS) deed does not indicate more than preference" (Mirzaye Qomi, Manahej-Al-Ahkam fi Masa'el-Al-Halal-e-va-Al-Haram, 1999, p. 142).

\section{The Difference between Words and Deeds}

Words and sayings by the Holy Prophet (PBUH) and Imams (AS) which are included in narrations and hadiths are called (Words of the Holy Prophet (PBUH) and Imams (AS)). Deeds done by the Holy Prophet (PBUH) and Imams (AS), although absent in their words, are called (Deeds of the Holy Prophet (PBUH) and Imams (AS)).

In regard to the difference between words and deeds, Ayatollah Montazeri says: "Although the Holy Prophet (PBUH) and Imams' (AS) deeds are reasonable, they are not unconditional and they depend on the conditions of time and place, unlike the Holy Prophet (PBUH) and Imams' (AS) words" (Montazeri, 1988, p. 367).

Therefore, the Holy Prophet (PBUH) and Imams' (AS) words, in case of being thorough in terms of evidence and implication, can be the base for Fatwa and inference of religious order for jurisprudents since they have precision. However, the Holy Prophet (PBUH) and Imams' (AS) deeds, as being affected by time and place, cannot utterly be the base for religious orders since particular deeds may specifically belong to the Holy Prophet (PBUH) and Imams (AS). Some examples are the incumbency of night prayers or the will to have more than four wives which are specifically for the Holy Prophet (PBUH). It is possible in some cases that the Holy Prophet (PBUH) and Imams (AS) have applied a deed in urgent circumstances or for reservation.

According to all mentioned, in cases where religious orders are claimed by the Holy Prophet (PBUH) and Imams (AS), the jurisprudent or priest can refer to the words based on the conditions. As an example, rules for washing one's face in ablution can be inferred from the following hadith which is one the hadiths in this regard:

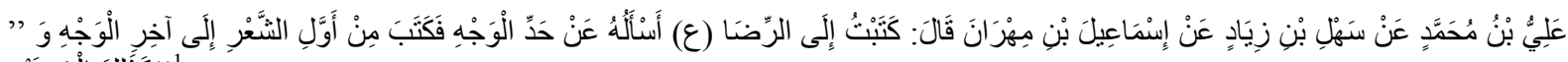

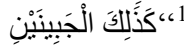

However, the Holy Prophet (PBUH) and Imams' (AS) deeds, in cases where God's commands are reflected in them, can be referred to by jurisprudents and priests under certain circumstances. Thus, jurisprudents and priests can issue fatwa on the basis of such deeds. As an example, in order to demonstrate the way the Holy Prophet (PBUH) used to make ablution, Imam Baqir (AS) asked for a bowl of water and started to make ablution.

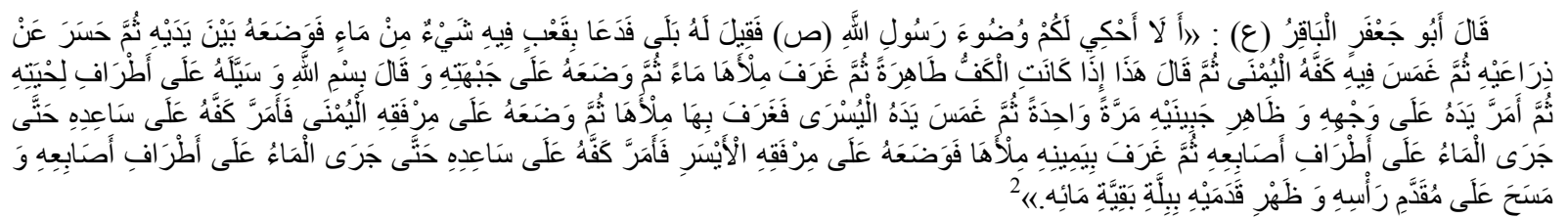

\footnotetext{
${ }^{1}$ Ismaeel-Ibn-e-Mahziyar says: "I wrote to Imam Reza (AS) asking him about the limits for washing face in ablution. He wrote in response: It starts from where the hair grows to the end of the face as well as around the forehead" (Kelini, Mohammad-Ibn-e- Eshaq, (ط - دار الحديث), 2008, Vol. 3, p. 28).

${ }^{2}$ Imam Baqer (AS) says: You do not want me to practically describe you the Holy Prophet's (PBUH) way of ablution? People said: We do. Imam (AS) asked for a wooden bowl with some water in it and put the bowl in front of him. Then, he pulled up his sleeves and put his hands into the water saying: It is done when your hands are clean. After that, Imam (AS) filled one of his hands with water and moved it to his
} 
Behbahani and Mohaqeq Khansari say: "This narration is correct. The deed is considered as a necessary statement which has turned into brevity. If the deed is in the form of a statement, it must be conformed to" (Behbahani, 2005, p. 293 \& Mohaqeq Khansari, p. 102).

It is clear that the deeds are religious justifications and the ablution quality must meet the standards of the Holy Prophet (PBUH) and Imams (AS).

\section{Reasonability Domain of the Holy Prophet (PBUH) and Imams' (AS) Deeds}

The implacability to the Holy Prophet (PBUH) and Imams' (AS) words is higher than the reasonability of their deeds; as in words, there is a higher potential to use words, phrases and certain parts of speech which thoroughly imply to the purpose and more evidently express the order. However, as far as deeds are concerned, if the deed is practiced by the Holy Prophet (PBUH) and Imams (AS), the implication is that the deed is permissible and allowed to be done, but it does not indicate the incumbency or recommendation of the deed. However, if the deed is not practiced by the Holy Prophet (PBUH) and Imams (AS), the implication is that the deed is not at least necessary, but there is no implication to the unlawfulness or abomination of the deed unless there is another reason or sign to indicate that the deed is necessary, recommended, unlawful or abominable.

Concerning the reasonability domain of the Holy Prophet (PBUH) and Imams' (AS) deeds, late Mozaffar says: "There is no doubt that the deed, as belonging to the Holy Prophet (PBUH) and Imams (AS), is at least implied to the permissibility of the deed. However, the abandoned deed has the implication that the deed is not necessary. The implication of the deed to permissibility or non-incumbency, if the innocence is proved for the Holy Prophet (PBUH) and Imams (AS), is undoubtedly correct."

The implication of the deed to what is higher than permissibility or non-incumbency, if the deed is accompanied by indication, means the Holy Prophet (PBUH) and Imams (AS) are expressing an order of orders or worship. Such being the case, based on the existing indication, the deed indicates that it is necessary or recommended. There is no doubt that such a deed, like the appearance of words, is the absolute justification. There is no disagreement between jurisprudents in such cases. Disagreement emerges when the Holy Prophet (PBUH) and Imams' (AS) deed lacks indication. In such cases, some jurisprudents say that the deed is implied to incumbency for non-innocence. Some also say that the deed is implied to recommendation (Mozaffar, 1991, p. 58).

Mohaqeq Damad says: “There is no problem in that the Holy Prophet (PBUH) and Imams' (AS) deeds are considered as justification like their words. However, in one case, if the deed specifically belongs to the Holy Prophet (PBUH) and Imams (AS) and it is not allowed for someone else unless there is a reason, the words and claims will be unreliable. The reason is that this word requires the deed to lose its reasonability. If there is an indication to specification, the deed will lose its reasonability" (Mohaqeq Damad, 2: 632).

Ayatollah Makarem Shirazi also believes that the deed without indication does not imply to incumbency or recommendation. "Since words are more illustrative than deeds and transfer the message faster to the addressee, verbal orders by the Holy Prophet (PBUH) and Imams (AS) indicates incumbency and unlawfulness and such indications are to be referred. But, are the Holy Prophet (PBUH) and Imams' (AS) deeds implied to incumbency as their orders are? Is abandoning the deed implied to unlawfulness? Undoubtedly, the deeds are not implied to what is more than permit (non-unlawfulness). A deed practiced by the Holy Prophet (PBUH) and Imams (AS) only implies that the deed is not unlawful; however, the incumbency cannot be inferred from it, as abandoning a deed is only implied to non-incumbency but not to its unlawfulness unless there is an indication where the deed is implied to incumbency; for instance, when the Holy Prophet (PBUH) and Imams (AS) practice a deed aiming at teaching an order or a kind of worshipping or when the Holy Prophet (PBUH) and Imams (AS) constantly practice or abandon a deed which is believed by someone to be the reason for incumbency or unlawfulness" (Shirazi, 2009, p. 170).

\section{Type of Inferring Recommendation from the Holy Prophet (PBUH) and Imams' (AS) Deeds}

The grand jurisprudents sometimes refer to the Holy Prophet (PBUH) and Imams' (AS) deed as an independent reason in order to infer an order of religious orders. As an example, in discussing the recommendation of

forehead saying “بسم الَّم " and pouring water around his forehead. Then, he rubbed his hand on his face and on the sides of his forehead. Next, he put his left hand into the water, filled it and poured the water on his right elbow. Then he rubbed his left hand over his right arm until it was covered with water from the elbow to the fingertips. After that, he put his right hand into the water, filled it and poured the water on his left elbow. He rubbed his hand on his left arm in a way that the water started flowing over to the fingertips. Finally, Imam (AS) used the remaining drops of water on his hands for anointing the front part of his head as well as the upper surface of his feet (Sheikh Sadooq, Mohammad-Ibn-eAli-Ibn-e-Babviyeh, من لا يحضره الفقيه, 1995, Vol. 1, 37). 
repeated call to prayers, the jurisprudents not only agree on the recommendation of repeated call to prayers, but also refer to the narration by Mohammad-Ibn-e-Muslem.

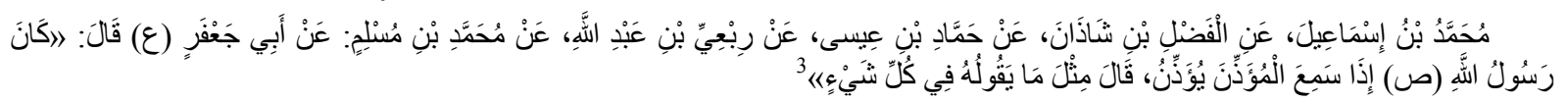

\subsection{Jurisprudents' Viewpoints}

The grand jurisprudents have inferred from this narration, which is the story of the Holy Prophet's (PBUH) deed told by Imam Sadeq (AS), that repeating a muezzin's call to prayers by another person (the listener) is recommended. In addition to the agreement, the grand jurisprudents' reason for such an inference is the Holy Prophet's (PBUH) action and behavior.

Feize Kashani says: "The story of repeating call to prayers for the listener is both agreed by the jurisprudents and implied to by Mohammad-Ibn-e-Muslim's narration" (Feize Kashani, 2008, p. 370). Also, Horre Ameli (Horre Ameli, 1991, p. 261), Ameli (Ameli, Seyyed Mohammad Hossein Tarhini, 2006, p. 156), Bahrani (Bahrani, Alhadaeq-Al-Nazerah, 1984, p. 422), Behbahani (Behbahani, 2005, p. 476), Mirzaye Qomi (Mirzaye Qomi, Qana'em-Al-Ayyam, 1996, p. 416), Naraqi (Naraqi, 1994, p. 537), Hamedani (Hamedani, 1996, p. 355), Hakim (Hakim, 1998, p. 575) and some other grand jurisprudents have inferred the recommendation of repeating call to prayers according to the agreement and the Holy Prophet's (PBUH) practical Sire as well as the consistency of his practice.

\section{Inference of Abomination from the Holy Prophet (PBUH) and Imams' (AS) Deed}

In cases where the Holy Prophet (PBUH) and Imams (AS) prohibit a deed while an Imam has done one of the same deeds, say, if a contradiction is seen between words and deeds in a subject, jurisprudents declare it as abomination or infer that in case of necessity or excuse, the practice of that prohibited deed will be allowed.

\section{Types of Inferring Abomination from the Holy Prophet (PBUH) and Imams' (AS) Deed}

In a narration, Imam Sadeq (AS) prohibits eating while walking. However, there are some other narrations in which the Holy Prophet (PBUH) eats as he walks.

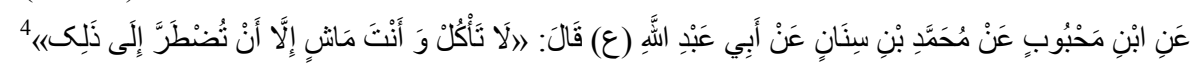

In two other narrations, Imam Ali (AS) and Imam Sadeq (AS) say that the Holy Prophet was eating while walking.

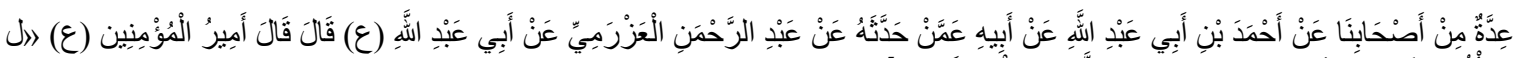

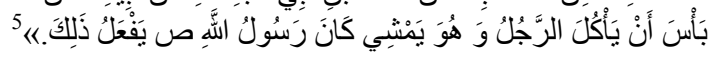

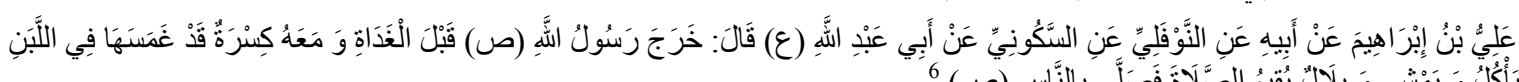

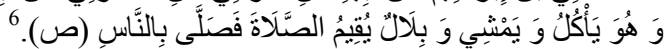

\subsection{Jurisprudents' Viewpoints}

According to these two types of narrations, the grand jurisprudents such as Sheikh Sadooq (Sheikh Sadooq, 1995, p. 600), Allameh Helli (Helli, Allameh, 2002, p. 648), Shahide Avval (Ameli , Shahide Avval, 1996, p. 27), Mohammad Taqi Majlesi (Majlesi Avval, 1985, p. 525), Hor Ameli (Ameli, Hor, 1991, p. 95), Saheb-Al-Javaher (Najafi, 1983, p. 470), Mohaddess Noori (Noori, 198, p. 230) and a group of scholars (A group of Researchers, 1996, p. 495) say: the Holy Prophet's (PBUH) deed was either for giving permit, i.e. regarding the prohibition of eating while walking, the deed was aimed at issuing the order so that no one might suppose that eating while walking is unlawful; or for necessity.

\section{Prohibition of Fasting on a Journey with Reference to the Holy Prophet (PBUH) and Imams' (AS) Deeds}

\footnotetext{
${ }^{3}$ Mohammad-Ibn-e-Muslim quotes Imam Baqer (AS): Whenever my forefather, the Holy Prophet (PBUH), heard the voice of muezzin, he repeated the verses along with him (Kelini, Mohammad-ibn-e-Yaqub-Ibn-e-Ishaq, الكافي) (طار الحديث), 2008, Vol. 6, p. 130).

${ }^{4}$ Mohammad-ibn-e-Sanan quotes Imam Sadeq (AS): Do not eat when you walk if you do not have to (Borqi, Ahmad-Ibn-e-Mohammad-Al-Mahasen, 1950, Vol. 2, 459).

${ }^{5}$ Imam Ali (AS) has been quoted: No matter eating while walking. The Holy Prophet (PBUH) used to do it (Kelini, Mohammad-ibn-e-Yaqub-Ibn-e-Ishaq, الكافي, 2008, Vol. 6, p. 273).

${ }^{6}$ Sokuni quotes Imam Sadeq (AS): The Holy Prophet (PBUH) left home for mosque before morning prayers holding a piece of bread dipped in milk. He was eating the bread while walking. Belal was calling to prayers. The holy Prophet (PBUH) said prayers with others (Kelini, Mohammad-ibn-e-Yaqub-Ibn-e-Ishaq, الكافي, 2008, Vol. 6, p. 273). The same narration exists in مستدرك الوسائل (A) were Imam Sadeq (AS) quotes his father who had quoted Imam Ali (AS) (Noori, مستدرك الوسائل و مستنبط المسائل, 1987, Vol. 16, p. 230).
} 
Another type of deeds referred to by jurisprudents is the prohibition of fasting on a journey whether fasting is necessary or recommended, except for some certain cases.

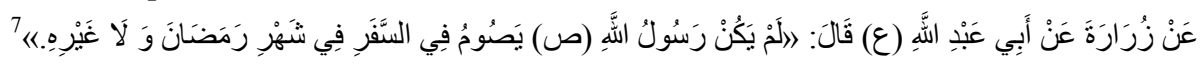

\subsection{Jurisprudents' Viewpoints}

With reference to the narrations about the Holy Prophet (PBUH) and Imams (AS) regarding recommended ablution on a journey, jurisprudents have shared three viewpoints.

A. The viewpoint of prohibition shared by Ibne Babviyeh ${ }^{8}$, Mofid ${ }^{9}$ and $\operatorname{Salar}^{10}$

B. The viewpoint of abomination shared by Sheikhe Toosi ${ }^{11}$, Ibne Baraj ${ }^{12}$ and Ibne Edris ${ }^{13}$; Mohaqeq in Sharaye (Mohaqeq Helli, 1990, p. 189) and Saheb Javaher (Najafi, 1983, p. 338) have also confirmed this viewpoint.

\section{The viewpoint of permit without abomination}

Those who believe in the prohibition of fasting on a journey have referred to the narration by Zarareh suggesting the Holy Prophet's (PBUH) deed. They have referred to the narration by Mohammad-Ibn-e-Muslim about Imam Sadeq (AS) as well.

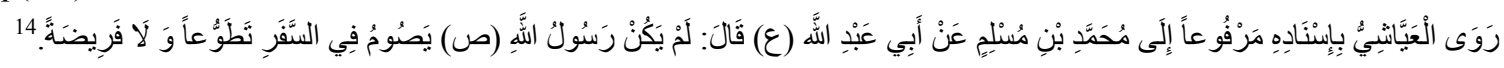

\section{Inferring the Incumbency of Washing and Anointing Parts of Ablution Once}

One type of inferring orders from the Holy Prophet (PBUH) and Imams' (AS) deeds and behavior is the inferring the order of incumbency for which jurisprudents have used the practical Sire of the Holy Prophet (PBUH).

In his practical Sire, the Holy Prophet (PBUH) would not wash and anoint parts of ablution more than once.

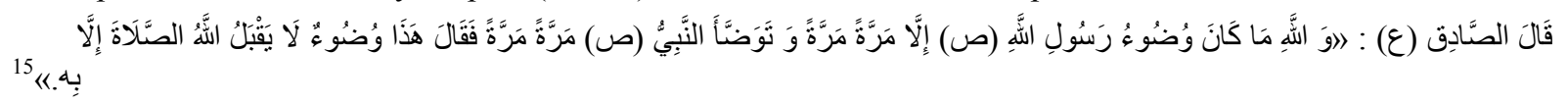

\subsection{Jurisprudents' Viewpoints}

Allameh Helli says: "This narration holds the incumbency of ablution and the Holy Prophet (PBUH) and Imams' (AS) deeds. Thus, violating what is practiced by the Holy Prophet (PBUH) and Imams (AS) is not allowed. However, it is of no conflict if we have inferred the recommendation of washing twice from another reason" (Helli, Allameh, 2002, p. 284).

Seyyed Nematollah Jazayeri has criticized Allame Helli's remark saying: "First, it is discovered from the surface of the narration that such a deed was in constant practice by the Holy Prophet (PBUH) and Imams (AS) and did not belong to a certain case. Second, these narrations are used to demonstrate that there was no multiplicity in the Holy Prophet (PBUH) and Imams' (AS) ablution. Third, the claim of consensus referring to Ibne Edris in that washing twice is considered as virtue lacks conformity with its reason" (Jazayeri, 1992, p. 479).

Seyyed Mohammad Tabatabaee Karbalaee reacts to this narration being mursala. He believes that the reasonability of this mursala is inferred from some of Allame's works, since Allame has said that a group of scholars such as Allame Helli, Mohaqeq Helli, Shahide Avval, Shahide Dovom and Mohaqeq Sani have reasoned upon this narration (Tabatabaee Karbalaee, 1994, p. 285).

With reference to this narration, the author of Yanabee-Al-Faqiheh writes: “Ablution is made only once. There is

\footnotetext{
${ }^{7}$ Zarareh quotes Imam Sadeq (AS): The Holy Prophet would not fast on journey, neither in Ramadan nor in any other months (Toosi, تهذيب الأحكام (Research of Khorasan), 1999, Vol. 4, p. 236).

${ }^{8}$ He would not fast on journey, neither as recommended nor as necessary (Sadugh-e-Avval, Ali-Ibn-e-Babviyeh, A Collection of Fatwa by Ibn-e-Babviyeh, p. 74).

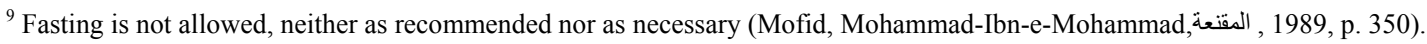

${ }^{10}$ A passenger dose not fast, neither as recommended nor as necessary (Deilami, Sallar, Hamzat-Ibn-e-Abdolaziz, 1996, p. 97).

${ }^{11}$ Recommended fasting on journey is abominated in any way (Toosi,النهاية في مجرد الفقه و الفتاوى, 1992, p. 162).

${ }^{12}$ Thus, recommended fasting on journey is abominated (Terablosi, المهذب لابن البراج, 1988, Vol. 1, p. 194).

${ }_{13}^{13}$ Recommended fasting on journey is abominated in any way (Ibn-e-Edris, Mohammad-Ibn-e-Mansour, السر ائر الحاوي لتحرير الفتاوى, 1989, Vol. 1, p. 393)

${ }^{14}$ Mohammad-Ibn-e-Moslem quotes Imam Sadeq (AS): The Holy Prophet would not fast on journey, neither as recommended nor as necessary (Horre Ameli, Mohammad-Ibn-e-Hassan, وسائل الثيعة, 1991, Vol. 10, p. 204).

${ }^{15}$ In this respect, Imam Sadeq (AS) says: I swear to God the Holy Prophet (PBUH) made ablution only once (He used to wash and anoint each part only once). Once he made ablution and said: This is the only way of making ablution accepted by God for saying prayers (Sheikhe Sadooq, Mohammad-Ibn-e-Ali-Ibn-e-Babviyeh, من لا يحضره الفقيه, 1995, Vol. 1, p. 38).
} 
no reward in the second time and the third time is considered innovation."

There is another narration including the practical Sire of the Holy Prophet (PBUH) and Imams (AS) on washing parts of ablution once.

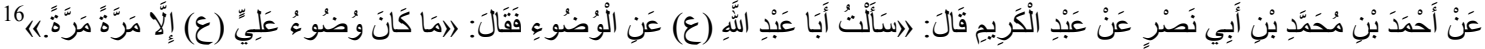

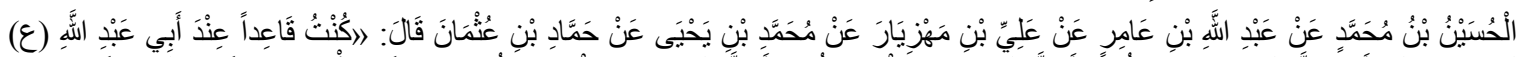

\section{Supposing the Holy Prophet (PBUH) and Imams' (AS) Deeds as Reservation}

In cases where the Holy Prophet (PBUH) and Imams' (AS) deed is in contradiction to the jurisprudence foundations of Shia, the grand jurisprudents decide to either explicate the deed by supposing it as reservation or mention another excuse or necessity for it.

One of the distinction points between Shia and Sunni is completely or partly reciting a sure in prayers. The Sunni religion allows for partly reciting, but the Shia religion does not.

\section{Practical Type of Supposing as Reservation}

There are many cases in the narrations including the Holy Prophet (PBUH) and Imams' (AS) deeds where the deeds are not apparently practiced based on the foundations of Shia jurisprudence. In such cases, the grand jurisprudents explicate the deed or suppose it as reservation.

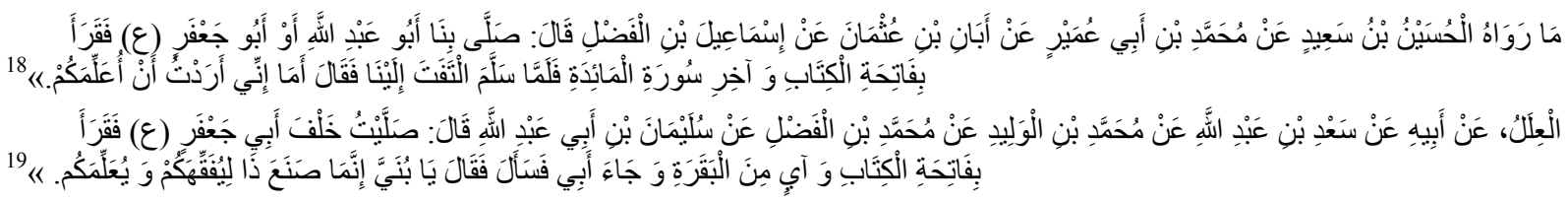

\subsection{Jurisprudents' Viewpoints}

Most jurisprudents have supposed this narration and narrations alike to be a way of teaching reservation.

Feiz Kashani says: "The intention of training may be giving the permit for sura discrimination although non-discrimination is better. The author of Tahzibin, Sheikh Toosi has inferred teaching reservation from training since he has supposed a similar narration as reservation. However, there are problems in his reasoning" (Horre Ameli, 1991, p. 46).

Allame Helli has quoted this narration saying: "According to most of our jurisprudents such as Seyyed Morteza in Entesar, Sheikh Toosi in Khelaf and Mohaqeq Helli in Sharaye, partly reciting a sura is not allowed. However, Sheikh Toosi's opinion in Nahaye is the opposite. In some cases, recitation of some verses of a sure is allowed. Based on necessities, in supererogatory prayers for someone who is illiterate with no learning abilities or in cases where there is not enough time to say prayers, recitation of some parts of a sura without misdeed is allowed. Sheikh Toosi says in Almabsoot: Recitation of Sura of Tawheed is necessary after Sura of Fatiha, but if it is partly recited, the prayers will not be revoked" (Helli, Allame, 2002, p. 59).

Shahide Avval says: "According to what was popular among the companions, complete recitation of Sura of Tawheed is necessary after recitation of Sura of Fatiha. Ibne Jonayd, Salar and Sheikhe Toosi in Nahayeh and Mohaqeq in Motabar have given an opposite comment. They believe in the complete recitation of Sura of

\footnotetext{
${ }^{16}$ Abdolkarim says: I asked Imam Sadeq (AS): How to make religious ablution? Imam (AS) answered: Imam Ali (AS) used to wash his face and hands only once and anointed his feet and head only once (Sheikh Kalini, Mohammad-Ibn-e-Yaqub, الكافي ط الإسلامية, 1984, Vol. 3, p. 27).

${ }^{17}$ Hamad-Ibn-e-Osman says: I was sitting in Imam Sadeq's (AS) presence. He ordered for water. When water arrived, he took a handful of it to wash all his face. Then, he took a handful of water and washed his right forearm. Next, he took a handful of water and washed his left forearm. Finally, he anointed the front part of his head as well as the upper surface of his feet and said: This ablution belongs to the person who does not innovate, i.e. who does not go beyond the pre-established divine limits (Sheikh Kalini, Mohammad-Ibn-e-Yaqub, الكافي ط الإسلامية Vol. 3, p. 27).

${ }^{18}$ Ismaeel-Ibn-e-Fazl says: Imam Sadeq (AS) or Imam Baqer (AS) said prayers with us. He recited Sura of Fatiha and the end of Sura of Maidah. After saluting the prayers, he looked at us and said: I had the intention of giving you training (Toosi, Aboo Jafar, Mohammad-Ibn-e-Hassan, الإستبصار فيما اختلف من الأخبار 1992, Vol. 1, p. 316; Toosi, Aboo Jafar, Mohammad-Ibn-e-Hassan, تهذيب الأحكام (Research of Khorasan), 1999, Vol. 2, p. 294; Horre Ameli, Mohammad-Ibn-e-Hassan,وسائل الثشيعة ر , 1991, Vol. 6, p. 46).

${ }^{19}$ Mohammad-Ibn-e-Fazl quotes Soleiman-Ibn-e-Aboo-Abdollah: I said prayers after Imam Baqer (AS). He recited Sura of Fatiha and a verse from Sura of Baqare. When my father arrived, I asked him about Imam's (AS) deed. He answered: Dear son, Imam (AS) had the intention of giving you training (Allameh Majlesi, Mohammad Baqer, بحار الأنوار ط - بيروت, 1981, Vol. 82, p. 28; Horre Ameli, Mohammad-Ibn-e-Hassan,وسائل الثيعة, 1991, Vol. 6, p. 46).
} 
Tawheed after Sura of Fatiha as recommended. They also allow for discrimination or sometimes abandoning the recitation of Sura of Tawheed. This narration and the other narrations in this regard which order for discriminating Sura of Tawheed are taken as reservation since most companions' deeds are in contradiction to them. Their opposition indicates their disclaimer of this narration" (Ameli, 1996, p. 302).

The author of Javaher believes in the necessity of reciting Sura of Tawheed after Sura of Fatiha according to the practical Sire of the Holy Prophet (PBUH), Imam Ali (AS) and Imam Reza (AS) (Najafi, 1983, p. 333).

Mohammad Ameli says: "The narration by Ismaeel-Ibn-e-Fazl and other related narrations indicate the permissibility of discriminating Sura of Tawheed after Sura of Fatiha" (Ameli, 2006, p. 348).

Abu Jafar Ameli says: "This narration is supposed to reservation, not authority" (Ameli, Abu Jafar, 1998, p. 149).

Some of the grand jurisprudents have commented on the narration by Soleiman-Ibn-e-Abu-Abdollah as the following:

Majlesi says: "This narration seems to have been changed. It may be narrated by Soleiman-Ibn-e-Abdollah-Ibn-e-Hassan and Abdollah may be the person who was asked. Polygraphs may have added the prefix "Abi". In both narrations, the aim of training may have been training for giving permit to partly recite Sura of Tawheed or not to recite it at all. Most jurisprudents have perceived this narration like this. Or, the aim of training may have been training for reservation as claimed by Sheikh in Tahzib. Sheikh's claim is notable since this case is not the case of reservation and saying prayers in the form of reservation in any case other than reservation is unlikely, unless it is claimed that saying prayers is based on non-incumbency of reciting the whole Sura of Tawheed and Imams' (AS) training as reservation is abandoning reservation and partly reciting Sura of Tawheed or the prayers are taken as recommended which can be said in congregational prayers or the prayers are sign prayers. Therefore, given all mentioned, recitation of the whole Sura of Tawheed is of absolute non-incumbency" (Majlesi, 1983, p. 28).

\section{Quality of Reasoning the Holy Prophet (PBUH) and Imams' (AS) Deeds}

It has been said that the Holy Prophet (PBUH) and Imams' (AS) deeds, like their words, are the second source of inferring religious orders after the Holy Quran. Discovering the way grand jurisprudents use and reason such deeds in order to prove their claims requires a discussion and investigation on the quality of grand jurisprudents' reasoning concerning the Holy Prophet (PBUH) and Imams' (AS) deeds.

\subsection{Type of Reasoning as a Support for Reason}

In some cases, jurisprudents have used the practical Sire of the Holy Prophet (PBUH) and Imams (AS) as a support to prove a religious order or subject. In other words, they have based the main reasons for proving an order on verses and narrations and referred to the practical Sire as a support.

In the discussion of three-stage stoning the devil in Hajj rituals, Ibne Edris says: Three-stage stoning the devil for three days is necessary. The reason for this incumbency is constant news. The Holy Prophet (PBUH) and Imams' (AS) deeds are implied to this discussion (Ibn-e-Edris Helli, 1989, p. 607).

\subsection{Type of Reasoning as an Independent Reason}

In some cases, the grand jurisprudents have referred to the Holy Prophet (PBUH) and Imams' (AS) deeds as independent reasons. Regarding females' marriage, to understand if silence is the sign of agreement or not, the jurisprudents have referred to the Holy Prophet's (PBUH) deed.

In his book Amali, Sheikhe Toosi refers to his professor Sheikhe Mofid about his reference to Imam Ali (AS):

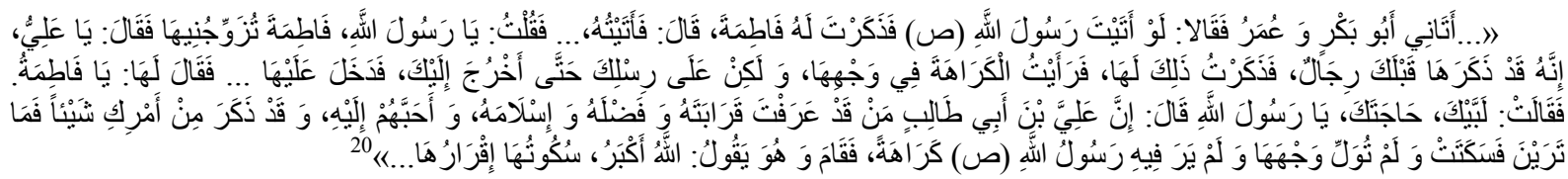

\footnotetext{
${ }^{20}$ In his book Amali, Sheikhe Toosi quotes his professor Sheikhe Mofid who had referred to Imam Ali (AS): Abubakr and Omar came to me and said: What if you went to the Holy Prophet (PBUH) and talked to him about your marriage to Fatima (SA)? Imam answered: I went to the Holy Prophet (PBUH) ... and said: Oh Holy Prophet, now that silence is the sign of agreement, please let me marry Fatima (SA).

The Holy Prophet said: Oh Ali, some other men had made this proposal, but whenever I shared their proposal with Fatima (SA), I would notice disagreement in her face. Now, you have to wait for a while so that I may go to Fatima (SA) to share your proposal with her. Thus, the Holy Prophet (PBUH) went to Hazrat Fatima (SA) and said to her: My dear daughter... Fatima (SA) answered: Feel free to say whatever you want to dear father. Then, the Holy Prophet (PBUH) said: Ali-Ibn-e-Abi-Taleb who you know is a relative of ours, whose superiority over
} 
With regards to females' marriage, Mohammad Baqer Behbahani says: Although silence cannot be the sign of agreement and it is not allowed in religion to consider silence as the sign of agreement, in a certain case such as females' marriage, due to girls' modesty, it is allowed to consider silence as the sign of agreement. The reason for such permit to consider silence as the sign of agreement is the Holy Prophet's (PBUH) deed in the story of Imam Ali (AS) and Hazrat Fatemeh Zahra's (SA) marriage.

When the Holy Prophet (BPUH) shared Imam Ali's (AS) proposal for marriage with his daughter Hazrat Fatemeh Zahra (SA), she remained silent; thus, the Holy Prophet (PBUH) considered her silence as the sign of agreement and married Imam Ali (AS) and Hazrat Fatemeh Zahra (SA) (Behbahani, 2005, p. 566).

\section{Discussion and Conclusion}

There are four foundations in Imami jurisprudence used for inferring and deriving religious orders. These four foundations include: the Holy Quran, Sire, consensus and wisdom which are known as "the four reasons".

The practical Sire of the Holy Prophet (PBUH) and Imams (AS) is the subset of "Sire" and has no difference from the verbal Sire of the Holy Prophet (PBUH) and Imams (AS) in terms of reasonability.

Religious orders which are inferred from the four reasons are divided to five parts: necessary, unlawful, abominable, recommended and permissible.

Shiite jurisprudents believe that only the authentic hadith is reliable. It means that the narrator of the hadith must be Shiite, just or at least someone honest and trusted.

It is also believed that the practical Sire of the Holy Prophet (PBUH) and Imams (AS), like their words, is the base for inferring from religious orders.

The implacability to the Holy Prophet (PBUH) and Imams' (AS) words is higher than the reasonability of their deeds; as in words, there is higher potential to use words, phrases and certain parts of speech which thoroughly imply to the purpose and more evidently express the order. However, as far as deeds are concerned, if the deed is practiced by the Holy Prophet (PBUH) and Imams (AS), the implication is that the deed is permissible and allowed to be done, but it does not indicate the incumbency or recommendation of the deed. However, if the deed is not practiced by the Holy Prophet (PBUH) and Imams (AS), the implication is that the deed is not at least necessary, but there is no implication to the unlawfulness or abomination of the deed unless there is another reason or sign to indicate that the deed is necessary, recommended, unlawful or abominable.

There is no doubt that the deed, as belonging to the Holy Prophet (PBUH) and Imams (AS), is at least implied to the permissibility of the deed. However, the abandoned deed has the implication that the deed is not necessary. The implication of the deed to permissibility or non-incumbency, if the innocence is proved for the Holy Prophet (PBUH) and Imams (AS), is undoubtedly correct.

The implication of the deed to what is higher than permissibility or non-incumbency, if the deed is accompanied by indication, means the Holy Prophet (PBUH) and Imams (AS) are expressing an order of orders or worship. Such being the case, based on the existing indication, the deed indicates that it is necessary or recommended.

As far as evidence and implication are concerned, the narrations expressing the practical Sire of the Holy Prophet (PBUH) and Imams (AS) are not different from those expressing their verbal Sire.

Types of the Holy Prophet (PBUH) and Imams' (AS) practical Sire convey recommendation, incumbency, etc as their verbal Sire does. In cases where the Sire is in contradiction to the foundations of Shia jurisprudence, it is investigated in different aspects and sometimes taken as reservation.

\section{References}

A Group of Researchers Supervised by Shahroodi, Seyyed Mahmood Hashemi. (1996). الغدير , معجم فقه الجواهر . للطباعة و النشر و التوزيع.

Allameh Majlesi, M. B. (1981). بحار الأنو ار ط - بيروت, 1981, Vol. 82, p. 28.

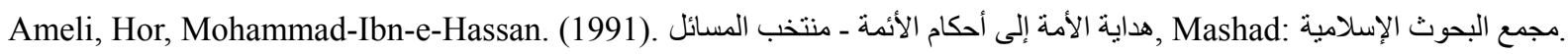

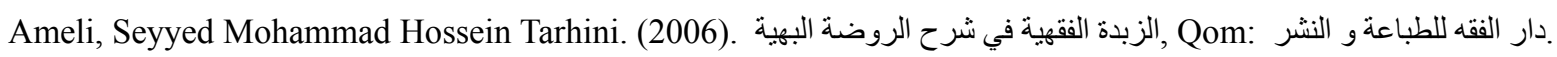

Ameli, Shahide Avval, Mohammad-Ibn-e Makki. (1996). الدروس الثر عية في فقه الإمامية, Qom: Islamic Publications

others and whose quality of faith you are aware of has proposed marriage to you. You know I have asked God to choose you for the best of his servants. Now, what is your opinion about that? Fatima (SA) did not say anything. She remained silent and looked away with modesty. The Holy Prophet (PBUH) arose as he said to himself: Allahu Akbar! God is great. Fatima's (SA) silence is the sign of her agreement (Toosi, 1987, p. 40). 
Office.

Bahrani, Al-e-Asfoor, Yousef-Ibn-e-Ahmad-Ibn-e-Ebrahim. (1984). الحدائق الناضرة في أحكام العترة الطاهر, Qom: Islamic Publications.

Behbahani, Mohammad Baqer. (2003). مصابيح الظلام, Qom: مؤسسة .العلامة المجد الوحيد البهبهاني

Behbahani, Mohammad Baqer. (2005). حاثية الو افى, Qom: مؤسسة العلامة المجدد الوحيد البهبهاني.

Borqi, Ahmad-Ibn-e-Mohammad-Ibn-e-Khaled. (1950). المحاسن, Qom: دار الكتب الإسلامية.

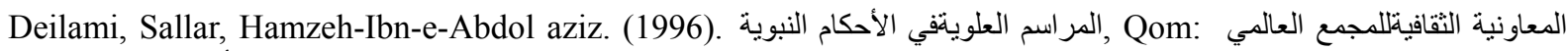
(ع) لأهل البيت

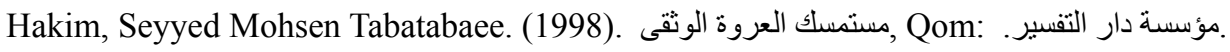

Hamedani, Aqa Reza. (1996). مصباح الفقيه, Qom: المؤسسةالجعفريةتلإحياءالتراثئ.

Helli, Allameh, Hassan-Ibn-e-Yusef-Ibn-e-Motahhar Asadi. (2002). تحرير الأحكام الثرعية على مذهب الإمامية, Qom: Imam Sadeq (AS) Institute.

Horre Ameli, Mohammad-Ibn-e-Hassan. (1991). وسائل الثيعة, Qom: مؤسسة آل البيت عليهم السلام.

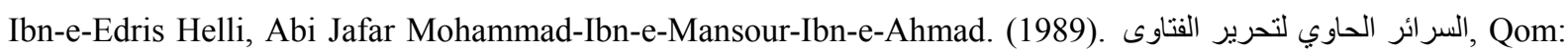
مؤسسةالنشر الإسلامي التابعةلجماعةالمدرسين بقم المشرفة.

Kashani, Feiz, Mohammad Mohsen-ibn-e Shah Morteza. (2008). معتصم الثيعة في أحكام الشريعة, Tehran, Supreme School of Shahid Motahhari.

Kelini, Mohammad-Ibn-e-Yaqub-Ibn-e-Eshaq. (2008). الكافي (ط ـ دار الحديث), Qom: دار).

Majlesi, Mohammad Baqer-Ibn-e Mohammad Taqi. (1983). دار الكتب : Tehran مرآة العقول في شرح أخبار آل الرسول الإسلامية.

Majlesi Avval, Mohammad Taqi. (1985). روضة المنقين في شرح من لا يحضره الفقيه, Qom: Kushanbur Islamic Cultural Institute.

Mirzaye Qomi, Abolqasem-Ibn-e Mohammad Hassan. (1996). غنائم الائّام في مسائل الحلال و الحرام, Qom: Islamic Advertising Office.

Mirzaye Qomi, Abolqasem-Ibn-e Mohammad Hassan. (1999). مناهج الأحكام في مسائل الحلال و الحرام, Qom: Islamic Advertising Office.

Mofid, Mohammad-Ibn-e-Mohammad-Ibn-e-Noman. (1989). المقنعة, Qom: مؤسسةالنشر الإسلامي التابعةلجماعةالمدرسين. بقم المشرفة

Mohaqeq Helli, Najm-Al-din, Jafar-Ibn-e-Hassan. (1990). شر ائع الإسلام في مسائل الحلال و الحرام, Qom: Ismaeelian Institute.

Montazeri, Hossein Ali. (1988). Jurisprudence Foundations of Islamic Rule, Qom: Keyhan Publications.

Mozaffar, Mohammadreza. (1991). اصو ل الفقه ، Qom: Islamic Advertising Office.

Najafi, Saheb-Al-Javaher. (1993). Mohammad Hassan, جواهر الكلام في شرح شر ائع الإسلام, Beirut: دار إحياء التراث العربي. Naraqi, Mola Ahmad-Ibn-e Mohammad Mahdi. (1994). مستند الثيعة في أحكام الثريعة., Qom: هؤسعة آل البيت عليهم السلام.

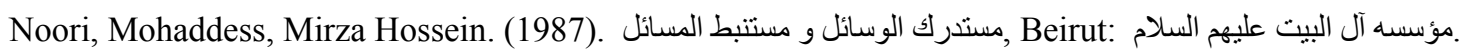

Sheikh Sadooq, Mohammad-Ibn-e-Ali-Ibn-e-Babviyeh. (1995). من لا يحضره الفقبه, Qom: Islamic Publications Office.

Shirazi, Nasser Makarem. (2009). دائرة المعارف فقه مقارن, Qom: School of Imam Ali (AS) Publications.

Tabatabaee Karbalaee, Seyyed Ali. (1994). رياض المسائل Q مؤسةالنشر الإسلامي التابعةلجماعةالمدرسين بقم المشرفة، : رمضان المبارك.

Terablosi, Ibn-e-Barraj, Qazi, Abdolaziz. (1988). المهذب لابن البراج, Qom: Islamic Publications Office.

Toosi, Abu Jafar, Mohammad-Ibn-Al-Hassan. (1992). النهاية في مجرد الفقه و الفتاوى, Beirut: دار الكتاب العربي.

Toosi, Mohammad-Ibn-Al-Hassan. (1999). تهذيب الأحكام (Research of Khorasan), Tehran: دار الكتب الإسلاميه.

Toosi, Mohammad-Ibn-e-Ali-Ibn-e-Hamzeh. (1987). الوسيلة إلى نيل الفضيلة, Qom: منشور ات مكتبة العظمى المر عشي النجفي الإسلة آيةالله. 


\section{Copyrights}

Copyright for this article is retained by the author(s), with first publication rights granted to the journal.

This is an open-access article distributed under the terms and conditions of the Creative Commons Attribution license (http://creativecommons.org/licenses/by/4.0/). 